\title{
Gebelikte COVID-19 hastalığının takip ve tedavisi
}

\section{Follow-up and treatment of COVID-19 disease in pregnancy}

\author{
Tuğba SARI*
}

Pamukkale ÜniversitesiTıp Fakültesi Enfeksiyon Hastalıkları ve Klinik Mikrobiyoloji Anabilim Dalı, Denizli/TÜRKIYE

\section{öz}

Tüm Dünya'da hızla yayılmaya devam eden, üzerinde birçok çalışma ve araştırmanın devam ettiği, birçok bilinmeyeni olan COVID-19'un gebelerdeki seyri de tartışmalıdır. Enfekte gebelerin çoğu (>\%90) hastaneye yatmadan iyileşse de, hızlı klinik bozulma meydana gelebilir ve semptomatik gebe hastalar, üreme çağındaki semptomatik gebe olmayan kadınlara kıyasla ciddi hastalık ve ölüm riski altında görünmektedir. Gebelikte ciddi hastalık ve ölüm için risk faktörleri arasında ileri yaş (özellikle $\geq 35$ yaş), obezite ve komorbiditeler (özellikle hipertansiyon ve diyabet veya birden fazla komorbidite) yer alır. Bu derlemenin amacı gebelerde COVID-19'un epidemiyolojisi, bulaş yolları, kliniği, komplikasyonları, tanısı, tedavisi, korunma önlemleri ve takibini özetlemektir.

Anahtar kelimeler: COVID-19; gebelik; SARS-CoV-2

\section{ABSTRACT}

The course of COVID-19 in pregnant women, which continues to spread rapidly all over the world, on which many studies and researches continue, and which has many unknowns, is also controversial. Although most (>90\%) infected pregnant women recover without hospitalization, rapid clinical deterioration can occur and symptomatic pregnant patients appear to be at greater risk of serious illness and death compared to symptomatic nonpregnant women of reproductive age. Risk factors for serious illness and death in pregnancy include older age (especially $\geq 35$ years), obesity and comorbidities (especially hypertension and diabetes or multiple comorbidities). The aim of this review is to summarize the epidemiology, transmission routes, clinic, complications, diagnosis, treatment, prevention measures and follow-up of COVID-19 in pregnant women.

Keywords: COVID-19; pregnancy; SARS-CoV-2

Sorumlu yazar*: Tuğba SARI, mukkale Üniversitesi Tıp Fakültesi Enfeksiyon Hastalıkları ve Klinik Mikrobiyoloji Anabilim Dalı, Denizli/TÜRKIYE 


\section{Giriş}

Tüm Dünya'da hızla yayılmaya devam eden, üzerinde birçok çalışma ve araştırmanın devam ettiği, birçok bilinmeyeni olan COVID-19'un gebelerdeki seyri de tartışmalıdır.

Bu yazıda gebelerde COVID-19'un epidemiyolojisi, bulaş yolları, kliniği, komplikasyonları, tanısı, tedavisi, korunma önlemleri ve takibi tartışılmıştır.

\section{A. Gebelerde COVID-19 epidemiyolojisi:}

Literatürdeki veriler, gebelik ve doğumun SARS-CoV-2 bulaşma riskini arttırmadığı ve COVID-19'un gebelerde gebe olmayanlara göre benzer bir seyir gösterdiği yönündeydi. Gebelerde hastalık seyri sırasında \%90'dan fazlası doğumdan önce iyileşmektedir. Her ne kadar COVID-19 için gebelik bir risk faktörü olarak bildirilmese de gebeliğin doğal seyri sırasında gelişen fizyolojik değişiklikler sebebi ile semptomların daha ciddi seyredebileceği göz önünde bulundurulmalıdır [1-8].

Bütün bunların tersine, Amerika Birleşik Devletleri'nde 90.000 'den fazla COVID-19 vakasının incelendiği raporda; gebelerin yoğun bakım ünitesine yatma $(\% 1,5$ 'e karşı $\% 0,9)$ ve entübasyon $\left(\% 0,5^{\prime}\right.$ e karşı $\left.\% 0,3\right)$ oranlarının, gebe olmayan kadınlara göre daha fazla olduğu bildirilmiştir [9]. Siyahi ırk ve İspanyol ırkındaki gebelerin ise SARS-CoV-2 enfeksiyonundan etkilenme oranının diğer gebelere oranla çok daha yüksek olduğu bildirilmiştir. Önceki verilerle uyuşmayan bu çalışma ile COVID-19'lu gebelerin yakından takip edilmesi gerektiği gösterilmiştir [10].

COVID-19 prevelansının yüksek olduğu New York'da yapılan çalışmaların birinde 215 gebe COVID-19 için taranmış ve dördü semptomatik olan 33 (\%15) gebe SARS-CoV-2 pozitif olarak bulunmuştur [181]. Diğer çalışmada da, başvuru sırasında asemptomatik olan ve SARS-CoV-2 pozitif 14 gebenin 10'u (\%71) doğum sırasında veya postpartum dönemde semptomatik hale gelmiştir [1]. Bu çalışma bulgularının, COVID-19 prevelansının daha düşük olduğu bölgelerde genellenmesi yanlış olabilir [10] . Prevelansın daha düşük olduğu Amerika'nın farklı bölgelerinde yapılan gebe taramalarında çoğunluğu asemptomatik olan SARS-CoV-2 pozitifik oranları \% 2,6-3,9 aralığında bildirilmiştir. [12-14].

\section{B. Gebelikte SARS-CoV-2 virus bulaş yolları:}

\section{B.1. Anneden Bebeğe Bulaş:}

Peripartum COVID-19 hakkında sınırlı bilgi mevcuttur birkaç olası in utero enfeksiyon vakası bildirilmiştir. Vertikal bulaş doğrulanmamakla beraber bu olasılık mevcuttur [15-19. Emzirmeyle bulaş riski için ise; birkaç anne sütü örneğinde virüs tespit edilmiştir. Emzirme sırasında yakın temas nedeniyle damlacık yoluyla yenidoğana bulaş olabilir [15, 20, 21].

\section{E. Gebelikte SARS-CoV-2 Tanısı}

Gebelikte SARS-CoV-2 enfeksiyonu tanı kriterleri gebe olmayanlarla aynıdır. Yeni başlayan ateş/titreme ve/veya solunum yolu semptomları (örn. öksürük, nefes darlığı), bulantı/kusma, ishal, baş ağrısı, koku/tat kaybı, boğaz ağrısı, kas ağrısı, halsizlik olan hastalarda COVID-19 olasılığı göz önünde bulundurulmalıdır.

Etyoloji açıklanamayan ciddi alt solunum yolu hastalığı olan hastalarda da düşünülmelidir. Son 14 gün içinde SARS-CoV2'nin toplumdan bulaştı̆̆ı bir yerde ikamet etmek veya oraya seyahat etmek veya doğrulanmış veya şüphelenilen bir COVID-19 vakasıyla yakın temas, şüpheyi artırmalıdır.

Test kriterlerini karşılayan hastalar, diğer solunum patojenleri (örn. İnfluenza, respiratuar sinsityal virüs) yönünden de test edilmelidir. Başka bir viral veya bakteriyel patojenin saptanması, SARS-CoV-2'yi dışlamaz. Enfeksiyonun yaygın olduğu bölgelerde, test yapılabiliyorsa, tüm hastalara doğum öncesi (veya elektif ise bir gün önce) SARS-CoV-2 testi önerilmektedir [10].

Tanıda kullanılan temel yöntem olan RT-PCR (reverse transkriptaz polimerazzincir reaksiyonu) testiCOVID-19 tanısını doğrulama amaçlı kullanılır ancakyanlışpozitifliği degörülebilir [22]. Yanlış negatiflik ise özellikle hastalık semptomlarından önceki dört gün ve semptomların ilk gününde alınan testlerde yanlış negatiflik görülebilmektedir [23-24]. Testin duyarlııı̆ı; örneğin kalitesi ve hastalık süresi gibi birkaç faktöre bağlıdır. Nazofarengeal örnekler, orofaringeal veya nazal örneklerden daha yüksek duyarlılığa sahiptir [22]. COVID-19 kliniği olan ve şüphesi devam eden hastalarda ilk test negatifse 24 saat ile birkaç gün içinde test tekrarlanmalıdır. Bu test süresince COVID-19 için enfeksiyon kontrol önlemleri devam etmelidir. İkinci alınan testin negatifliği genellikle enfeksiyonu dışlar ancak hastanın kliniğine göre karar verilmelidir [25]. COVID-19 enfeksiyonuna ilişkin klinik şüphe devam ediyorsa ve tedavi kararı için, daha yüksek duyarlılığa sahip alt solunum yolu örneklerinde (örn. balgam, bronkoalveolar lavaj) test tekrar edilebilir [26]. ELISA ve hızlı antikor testleri gibi Ig G ve Ig M'yi saptayan testlerin güvenilirliği hala tartışmalıdır.

Tanıda laboratuvar tetkiklerinin yanı sıra görüntüleme yöntemlerinin de duyarlılığı oldukça yüksektir. Akicğer grafisi ve toraks bilgisayarlı tomografisi (BT) gibi yöntemlerin içerdiği $\mathrm{X}$ ışınları ve radyasyon sebebi ile fetal teratojeniteye neden olabileceğine yönelik endişeler mevcuttur. COVID-19 tanılı hastaların ilk değerlendirmesi için akciğer grafisi yeterlidir. Tek bir grafi, 0.05 ila 0.1 rad arasında çok düşük radyasyon dozu 
taşır. Toraks BT için de fetal radyasyon dozu 1.5 rad olup, oldukça düşüktür. Gebelikte güvenli radyasyon doz sınırı 5 raddır. Yapılan çalışmalarda BT görüntülemenin fetal anomaliler veya gebelik kaybı riskini arttırmadığı gösterilmiştir. Bu yüzden gebelerin değerendirilmesinde gerekirse BT kullanılabilir. Bazı çalışmalarda COVID-19 tanılı gebelerin değerlendirilmesinde hızlı ve güvenilir olması nedeniyle toraks ultrasonografi yapılabileceği bildirilmiştir. Bilateral subplevral buzlu cam alanları ultrasonografide hiperekojen akciğer odakları şeklinde saptanabilmektedir $[27,28]$.

\section{Gebelikte Klinik Bulgular}

Tüm gebeler, özellikle doğrulanmış veya şüpheli vakalarla yakın temasta bulunmuşlarsa, COVID-19 semptom ve bulgularının gelişmesi açısından (gebe olmayan bireylerdekine benzer şekilde) izlenmelidir. Hastalık Kontrol ve Önleme Merkezi'nin (CDC) COVID-19 tanısı alan üreme çağındaki kadınların değerlendirildiği raporda, gebelerde (> 8200), gebe olmayan kadınlara (> 83.000) göre benzer oranda semptomatik vaka olduğu bildirilirken, gebelerin üçte birinde ve gebe olmayan kadınların \%10'nunda semptom durumunun bilinmediği bildirilmiştir [29].

Normal gebeliğin fizyolojik seyri sırasında görülen halsizlik, nefes darlığı, burun tıkanıklığı, bulantı/kusma gibi semptomlar, ateşsiz seyreden COVID-19 klinik bulguları ile karışabilir [10].

COVID-19 semptomları açısından gebeler gebe olmayanlar göre karşılaştırıldığında ise; öksürük (\%52'ye karşı \%54) ve nefes darlığı (\%30) semptomlarının benzer oranda baş ağrısı (\%41'e karşı \%52), kas ağrıları (\%38'e karşı \%47), ateş (\%34'e karşı \%42), titreme (\%29'a karşı \%36) ve ishal (\%14'e karşı \%23) gibi belirtilerin gebelerde daha az oranda görüldüğü bildirilmiştir. Boğaz ağrısı, burun akıntısı/burun tıkanıklığı, mide bulantısı / kusma ve koku ve / veya tat kaybı daha az görülen semptomlardır.

Gebelerde COVID-19 enfeksiyonu sırasında en sık saptanan laboratuvar bulguları ise; \%47 lenfopeni ve \%17 karaciğer enzimlerinde hafif artış olarak bildirilmiştir [30].

Hastalık şiddetinin sınıflandırılması: Amerika Birleşik Devletleri'nde, Ulusal Sağlık Enstitüleri, gebe olmayan kişilerde hastalık şiddetini şu şekilde sınıflandırmıştır [31].

- Asemptomatik veya presemptomatik enfeksiyon: SARSCoV-2 testi pozitif ancak semptom yok.

- Hafif hastalık: Nefes darlığı olmayan veya akciğer görüntülemesi normal olan, ancak ateş, öksürük, boğaz ağrısı, halsizlik, baş ağrısı, kas ağrısı gibi klinik semptomu olanlar
- Orta derecede hastalık: klinik değerlendirme veya görüntüleme ile pnömoni saptanan ve oda havasında oksijen satürasyonu (SaO2)> yüzde 93 olanlar

- Şiddetli hastalık: takipne (Solunum sayısı> 30/dk), oda havasında $\mathrm{SaO} 2 \leq \%$ 93, arteriyel kısmi oksijen basıncının solunan oksijen fraksiyonuna oranı ( $\mathrm{PaO} 2$ / FiO2) <300 veya $>\% 50$ akciğer parankiminde tutulum olanlar

- Kritik hastalık: Solunum yetmezliği, septik şok ve / veya multipl organ disfonkiyonu.

Enfekte gebelerin çoğu (>\%90) hastaneye yatmadan iyileşse de, hızlı klinik bozulma meydana gelebilir ve semptomatik gebe hastalar, üreme çağındaki semptomatik gebe olmayan kadınlara kıyasla ciddi hastalık ve ölüm riski altında görünmektedir. Gebelikte ciddi hastalık ve ölüm için risk faktörleri arasında ileri yaş (özellikle $\geq 35$ yaş), obezite ve önceden var olan komorbiditeler (özellikle hipertansiyon ve diyabet veya birden fazla komorbidite) yer alır [32]. Gebelerde klinik seyir üzerine yapılan çalışma sonuçlarına göre;

New York'da SARS-CoV-2 enfeksiyonu olan 241 gebe kadından oluşan prospektif bir kohort çalışmada, gebelerin \%61'i başvuru sırasında asemptomatik iken, bunların \%30'u doğumdan önce semptomatik hale gelmiştir [33].

Doğum hastanesine yatış sırasında COVID-19 saptanan gebelerin \%27'sinin hafif, \%26'sının şiddetli ve \%5'inin kritik olduğu bildirilmiştir. Şiddetli hastalık tablosunun, erken gebeliğe kıyasla özellikle komorbiditesi olan gebelerde ileri gebelik haftalarında daha yaygın görüldüğü bildirilmektedir [34]. Toplam 538 gebenin incelendiği bir derlemede \%15'inde (32/209) şiddetli hastalık ve \% 1.4'ünde (3/209) kritik hastalık saptandığı ve \%3'ünde (8/263) maternal yoğun bakım ünitesi yatışı gerektiği bildirilmiştir [30].

Gebe kadınlarda COVID-19 enfeksiyonunda, preeklampside ve HELLP sendromunda (hemoliz, yüksek karaciğer enzimleri, düşük trombositler) görülen benzer laboratuvar anormallikleri (hemoliz, yüksek karaciğer enzim seviyeleri, trombositopeni) saptanabilir. Ayırıcı tanıda bu tanılar da dikkate alınmalıdır [35-37].

Ağır hastalık tablosunda olan bazı gebelerin sitokin salınım sendromuna benzer artmış inflamatuvar cevapla uyumlu laboratuvar bulgularının olduğu bilinmektedir. Gebeliğin normal immünolojik değişikliklerinin bu tablonun oluşumunu ve seyrini etkileyip etkilemediği bilinmemektedir [10].

\section{Gebelik Komplikasyonları}

SARS-CoV 2 enfeksiyonu komplikasyonları arasında akut solunum sıkıntısı sendromu ve miyokardiyal hasar bulunur, ancak diğer organ sistemleri de etkilenebilir [10]. 
Annede gelişen COVID-19 enfeksiyonunun ciddi sekelleri arasında uzun süreli ventilasyon desteği ve ekstrakorporeal membran oksijenasyonu (ECMO) ihtiyacı yer alır [38-40]. COVID-19 pnömonisi gelişen gebelerde, preterm ve sezaryen doğum riskinde artış olduğu görülmektedir [10]. Ayrıca literatürde, çoğu SARS-CoV-2 enfeksiyonundanönce sağlıklı olan gebelerde bazen çoklu organ yetmezliği ile kardiyopulmoner komplikasyonlardan kaynaklanan anne ölümleri bildirilmiştir [40-45]. Yüzde 0,1 ila 0,8'lik anne ölüm oranları COVID-19'a bağlanmıştır. Gebe olmayan, aynı yaştaki kadınlara kıyasla gebeliğin COVID-19 klinik seyri kötüleştirdiği saptanmıştır [29]. COVID-19'a sekonder görülen ateş ve hipoksemi, erken doğum, erken membran rüptürü ve fetal kalp hızında artış riskini artırabilir, ancak şiddetli solunum hastalığı olmayan hastalarda da erken doğumlar meydana gelebilir. Genel olarak maternal solunum yetmezliğinin normal doğumda artabileceği endişesiyle elektif sezeryan ile doğum yönelimi olmakla birlikte bu hipotez kanıtlanmamıştır.

Toplam 538 gebe COVID-19 hastasının incelendiği bir derlemede, \%20'sinin 37 haftadan önce ve \% 85'inin sezaryen ile doğum yaptığını bildirilmiştir [30]. İngiltere'de doğrulanmış COVID-19 tanısı olan 427 gebenin incelendiği prospektif bir kohort çalışmada, \%27'si preterm ve \%59'u sezaryen ile doğum yaptığı bildirilmiştir [40]. New York'ta doğrulanmış COVID-19 enfeksiyonu olan 241 gebede erken doğum oranı \%15 ve ciddi klinik seyri olanlarda sezaryen oranı \%52 ve kritik hastalığı olanlarda sezeryan oranı \%92'dir [33]. Bu çalışmalardaki semptomatik gebe oranı yüksek orandadır.

\section{D.1. Fetal Komplikasyonlar}

COVID-19 enfeksiyonuna sekonder spontan abortus sıklığı artmış gibi görünmemektedir, ancak gebeliğin ilk üç aylık döneminde geçirilen enfeksiyonlar ile ilgili veriler sınırlıdır $[46,47]$. Kritik klinik seyirli olan beş gebeliğin fetal ölümle sonuçlandığı bunların dördünde anne ölümü de gerçekleştiği birinde ise annenin halen ECMO'da olduğu bildirilmiştir [38,41]. Çalışma sonuçlarında yenidoğanların \%95'inden fazlası doğumda iyi durumda iken; neonatal komplikasyonlar büyük ölçüde erken doğumla ve kritik maternal hastalık nedeniyle oluşan olumsuz uterus koşullarıyla ilişkili bulunmuştur [41, 46, 48].

COVID-19 seyri sırasında görülen hiperterminin organogenez üzerine etkisine yönelik endişeler mevcuttur. İlk trimestirde geçirilen ateşli hastalıkların organogenezi etkilediği, nöral tüp defekti, düşük doğum ağırlığı gibi konjenital anomalilere neden olabileceği düşünülmekle birlikte bu sonuçlarla ilgili artmış bir insidans gözlenmemiştir. Ateş yüksekliği saptanan hastalarda; intrapartum ve postpartum enfeksiyonlar (örn. koryoamniyonit, endometrit) açısından da değerlendirilmeli ayrıca SARS-CoV-2 için PCR testi de istenmelidir. İlk üç aylık dönem de dahil olmak üzere gebelikte asetaminofen kullanımının genel olarak güvenli olduğu ve ateşe maruz kalma ile ilişkili gebelik risklerini azaltabileceği gösterilmiştir [10].

Üçüncü trimesterde birkaç peripartum maternal enfeksiyon vakasında olası horizontal geçiş bildirilmiştir, bu da konjenital enfeksiyonun olası olduğunu ancak yaygın olmadığını göstermektedir (maternal enfeksiyonların <\%3'ü) [49].

COVID-19 şüphesi olan veya doğrulanan annelerin bebekleri COVID-19 şüpheli olarak kabul edilir ve nazofarenks, orofarenks veya nazal bölgeden bir swab örneğinden RTPCR ile SARS-CoV-2 RNA için test edilmelidir. [50]. İlk test negatifse, tekrar testi yaklaşık 48 saat sonra yapılmalıdır; ancak $<48$ saatten sonra taburcu edilmesi beklenen asemptomatik yenidoğanlar için 24 ile 48 saat arasında yapılan tek bir test yeterlidir. Yenidoğanlarda akut enfeksiyonu teşhis etmek için serolojik test önerilmemektedir.

Toplam 936 COVID-19 ile enfekte anneden doğan bebeklerin incelendiği bir derlemede, doğumdan hemen sonra veya doğumdan 48 saat sonra alınan 27/936 (\%2,9) nazofaringeal numunede, $1 / 34$ kordon kanı numunesinde ve $2 / 26$ plasental örnekte neonatal viral RNA testi pozitif;; ek olarak SARS-CoV-2 serolojik incelemede 3/82 immünoglobulin M (lgM) pozitifliği bildirilmiştir [49].

Konjenital SARS-CoV-2 enfeksiyonu kanıtı için kabul edilmiş kesin kriterler bulunmamaktadır. Shah ve arkadaşları tarafından birtakım kriterler belirlenmiştir. Bu kriterler içerisinde maternal semptomlar ve temas durumu, maternal test sonuçları, yenidoğanın klinik durumu ve neonatal test sonuçları yer almaktadır [51].

\section{- Anne semptomatik ise;}

1-Kesin enfeksiyon : SARS-CoV-2 testi pozitif

2- Olası enfeksiyon: Test yok

3- Düşük olasılıklı enfeksiyon: Test negatif ancak semptomları açıklayacak başka bir bulgu yok

4- Enfekte değil: Negatif test ve semptomları açıklayacak başka bir neden var

\section{- Temaslı asemptomatik anneler;}

1- Kesin enfeksiyon : SARS-CoV-2 testi pozitif

2- Olası enfeksiyon: Tek bir negatif test 
3- Enfekte değil: Farklı zamanlarda alınmış iki testin negatif olması Konjenital SARS-CoV-2 enfeksiyonuna bağlı intrauterin fetal ölüm / ölü doğum, ancak virüsün fetal dokular veya plasental dokulardan virusun PCR ile tespiti veya dokudaki viral partiküllerin veya fetal/plasental doku kültüründe virusun elektron mikroskobi ile tespitiyle doğrulanır. Plasentanın bir fetal yüzeyinden veya fetal tarafından PCR ile virüs tespiti, olası enfeksiyon olarak sınıflandırılır. Virüs, yalnızca plasentanın maternal tarafından yüzey sürüntüsünde PCR ile tespit edilirse ve fetal veya plasental dokudan PCR ile virüs tespit edilmezse veya test yapılmazsa enfeksiyon olasıllığı düşüktür. Virüsün PCR veya otopside fetal dokularda elektron mikroskobu ile tespit edilmemesi enfeksiyonun olmadığını gösterir [10]. Literatürde şu ana kadar birkaç vaka dışında plasental örneklerin incelendiği çalışmalarda enfeksiyon kanıtı bildirilmemiştir [15, 18, 52-54].

COVID-19 hastalarında yapılan çalışmalarda viremi düzeyi yaklaşık \%1 oranında oldukça düşük tespit edilmiştir. $\mathrm{Bu}$ da plasental ve horizontal geçişin nadir olacağını düşündürmektedir [55].

SARS-CoV-2'nin hücreye girişinin, plasentada minimal olarak eksprese edilen anjiyotensin dönüştürücü enzim 2 (ACE 2) reseptörü ve serin proteaz TMPRSS2'ye bağlı olduğu düşünülmektedir [56, 57]. Bu da, plasental SARS-CoV-2 enfeksiyonunun ve fetal geçişin seyrek görülmesini açıklayabilir. Horizontal geçiş olup olmadığı tam kanıtlanmamakla birlikte şu ana kadar yenidoğandan ve plasental örneklerden alınan örneklerde SARS-CoV-2 RNA pozitifliği sapatanan iki olgu bildirilmiştir [15, 52]. Bu olgu bildirimlerinden birinde yendioğanda doğum sonrası hafif hipotermi, hipoglisemi ve prematüre ile uyumlu beslenme güçlükleri bildirilmiş, ancak solunum güçlüğü olmadığı bildirilmiştir. Diğer olguda ise doğum sonrası yenidoğan resüsitasyon yapıldığı, ancak altı saat içinde ekstübe edildiği ve ardından yaşamın 3. gününde sinirlilik, zayıf beslenme, eksenel hipertoni ve opistotonos geliştiği sonrasında ise iyileştiği bildirilmiştir.

Canlı doğan bir bebekte konjenital SARS-CoV-2 enfeksiyonu tanısı; yenidoğan ve annede enfeksiyonun klinik özelliklerinin varlığına veya yokluğuna bağlıdır. Semptomatik vakalarda, doğumdan sonraki ilk 12 saat içinde alınan kordon kanında veya yenidoğan kanında veya membran rüptüründen önce alınan amniyotik sıvıda PCR ile virüs tespit edilirse, konjenital enfeksiyon doğrulanır. Asemptomatik vakalarda, doğumdan sonraki 12 saat içinde alınan kordon kanı veya yenidoğan kanında PCR ile virüs tespit edilirse yenidoğan enfeksiyonu doğrulanır.
Yenidoğana intrapartum bulaş olabilir. Enfekte annelerin semptomatik yenidoğanlarında, doğumda (bebeği temizledikten sonra) ve 24 ila 48 saat arasında nazofaringeal sürüntüden alınan SARS-CoV-2 PCR'ının hem pozitif olması hem de semptomlar için alternatif bir tanı olmaması halinde intrapartum enfeksiyon doğrulanır.

Enfekte annelerin asemptomatik yenidoğanlarında, doğumda (bebeği temizledikten sonra) ve 24 ila 48 saat arasında nazofaringeal sürüntüden alınan SARS-CoV-2 PCR'nin her ikisi de pozitifse intrapartum enfeksiyon doğrulanır.

Yenidoğana doğum sonrası bulaş olabilir. Doğumda alınan solunum örneğinde SARS-CoV-2 PCR'ı negatifse ve daha sonra 24 ila 48 saat arasında alınan nazofarengeal sürüntüde iki PCR pozitif ise doğum sonrası bulaş düşünülebilir [10].

Yenidoğanlara bulaşın çoğunlukla SARS-CoV-2 enfeksiyonu olan anneler ve diğer bakıcılardan solunum damlacıklarına maruziyet ile olduğu düşünülmektedir $[30,58]$.

Nazofarenkste SARS-CoV-2 testi pozitif olan çoğu kadında iki olgu dışında, vajinal ve amniyotik sıvı örnekleri bugüne kadar negatif bulunmuştur $[52,59,60]$.

\section{E. COVID 19 şüpheli ya da tanılı gebeye yaklaşım}

\section{E.1. Evde İzlem:}

Şüpheli ya da kesin COVID-19 tanılı gebelerin çoğu (en az \%86) başka sebeple hastanede yatış gerekmiyorsa evde izlenebilir. Ancak obstetrik sorunların (örn., erken doğum eylemi) olmadığından, klinik durumun hızla bozulabileceği ihtimalinin olmadığından emin olunmalı ve olursa derhal hastaneye başvurması önerilmelidir [30]. Ayrıca üçüncü trimesterdeki gebelerde fetal hareket sayımı yapmalı ve fetal hareketin azaldığını bildirilmelidir. COVID 19 tanısı alan gebelerin en az iki hafta semptomları (nefes darlığı, taşipne, uygun asetaminofen kullanımına rağmen $39^{\circ} \mathrm{C}$ 'den yüksek aralıksız ateş, oral alamama) izlenmelidir [25].

\section{E. 2. Hastanede COVID 19 tanılı gebelerin izlemi:}

Hafif hastalığı ve komorbiditeleri (örneğin, hipertansiyon, pregestasyonel diyabet, kronik böbrek hastalığı, kronik kardiyopulmoner hastalık, immünosupresif durumlar) olanlar veya orta ila kritik hastalığı olan gebeler hastaneye yatırılır [61]. Kadın hastalıkları ve doğum uzmanı, perinatoloji, enfeksiyon hastalıkları, göğüs hastalıkları, anesteziyoloji ve reanimasyon ve yenidoğan uzmanlarının olduğu bir hastanede izlem yapılmalıdır.

Tüm gebeler, hastaneye yatış için hastaneye girmeden önce, COVID-19'un belirti ve semptomları (ateş ve / veya yeni öksürük, nefes darlığı, boğaz ağrısı, kas ağrıları, rinore / 
burun tıkanıklığı ve koku ve tat anormallikleri) açısından ve doğrulanmış bir vaka yakın temas olup olmadığı sorgulanmalı, ayrıca ateş ölçümü yapılmalıdır [62]. CDC, yatış sırasında COVID-19 şüphesi olan veya semptom gelişen gebelerde tarama testi önermektedir [63].

Amerika'da asemptomatik hastalar ve presemptomatik hastaların, sağlıkpersoneliveyenidoğan için riskoluşturabileceği göz önünde bulundurularak tüm doğum hazırlığı yapılan gebelere SARS-CoV-2 testi yapılmaktadır [64,65].

Gebelerde tek başına COVID-19 tanısı olması bir üst merkeze sevk için bir neden değildir. Ağır hastalığı, oksijen gereksinimi ile birlikte komorbiditeleri veya kritik hastalığı olan gebeler obstetrik hizmetlerin verildiği ve seviye III veya IV yetişkin yoğun bakım ünitesi (YBÜ) bulunan hastanede, diğer hastalara bulaş riski oluşturmayacak şekilde hazırlanan mümkünse negatif basınçlı izole bir odada takip edilmelidir. İzolasyon kurallarına uyularak travay takibi ve doğum sınırlı sayıda personelle gerçekleştirilmelidir. [23, 66]. ACOG (Amerikan College of Obstetrics and Gynecology) ve SMFM (Society for Maternal Fetal Medicine) tarafından hazırlanan COVID-19 tanılı gebe takibi algoritması şu şekilde sunulmuştur.

Ateş $\geq 38$ 凶eya öksürük, nefes darlığı, bulantı kusma/ishal semptomları varsa hastalık şiddeti değerlendirilmesi için; nefes darlığı, efor dispnesi, hemoptizi (bir çay kaşığından fazla), öksürürken göğüs ağrısı, disfaji, dehidratasyon, oryantasyon ve kooperasyon kısıtlılığı değerlendirilir. Herhangibiri saptanırsa hasta yüksek riskli olarak değerlendirilip izolasyon kurallarına riayet edilerek üst merkeze sevk edilir. Komorbidite, obstetrik sorunlar, sosyo ekonomik durum bozukluğu, özbakımda yetersizlik ve takipte zorluk söz konusuysa hasta orta riskli olarak değerlendirilir izlenmek üzere izole edilir, görüntüleme gerekliyse yapılır, solunum sıkıntısı gelişirse hasta yüksek risk kategorisinde değerlendirilir.

Rutin laboratuvar tetkiklerinin yanı sıra eşlik eden bakteriyel enfeksiyonlar için kan kültürleri de alınmalıdır. Sıvı elektrolit dengesi takip edilmelidir. Agresif hidrasyon akciğer ödemine yol açıp maternal oksijenasyonu kötüleştirebileceği için aldığı çıkardığı sıvı takibi yapılarak uygun <75 cc / saat hidrasyon yapılmalıdır [67]. Şiddetli COVID-19 kliniği olan gebeler için, hipotansiyon ve organ hipoperfüzyonundan kaçınılabilmek için konservatif sıvı tedavisi önerilir.

\section{F. Tedavi}

\section{F.1. Maternal Solunum Desteği:}

Kritik derecede hasta COVID-19 hastaları arasında, akut solunum sıkıntısı sendromundan (ARDS) kaynaklanan derin akut hipoksemik solunum yetmezliği sık görülür. Kritik hastalığı olan COVID-19 pnömonisinde uygulanan genel destek tedavisi, diğer nedenlere bağlı ARDS hastalarındakine benzerdir. COVID-19 ile ilişkili ARDS'nin yaygın komplikasyonları arasında akut böbrek hasarı, yüksek karaciğer enzimleri ve kalp hasarı (örn., kardiyomiyopati, perikardit, perikardiyal efüzyon, aritmi, ani kardiyak ölüm) bulunur.

Gebelik sırasında maternal periferik oksijen satürasyonu $(\mathrm{SpO} 2) \geq \% 95$ 'te tutulmalıdır. SpO2 \%95'in altına düşerse, kısmi oksijen basıncını (PaO2) ölçmek için bir arteriyel kan gazı alınmalıdır. Maternal taraftan fetal tarafına uygun bir oksijen difüzyon gradyanını sağlamak için maternal PaO2'nin 70 mmHg'den büyük olması gerekir. Dünya Sağlık Örgütü (WHO), hasta stabil olduktan sonra maternal SpO2'nin $\geq 92$ ila 95 oranında korunmasını önermektedir [68].

Yoğun Bakım Ünitesinde, COVID-19'lu ağır hastalar genellikle prone pozisyonda takip edilir. Uyku sırasında prone pozisyonunda uyuması gebede oksijen saturasyonunda artışa ve entübasyondan kurtulmaya olanak sağlamaktadır [69-71]. ARDS tedavisi için endike ise permisif hiperkapni (PCO2 <60 $\mathrm{mmHg}$ ) ve ekstrakorporeal membran oksijenasyonu (ECMO) fetüse zararlı değildir ve uygulanabilir, ancak veriler sınırlıdır $[74,75]$. Yüksek pozitif ekspirasyon sonu basınç stratejileri (> $10 \mathrm{mmHg}$ ), ön yükü ve kalp debisini azalttığı için yakın ve devamlı maternal ve fetal izlem gerektirir [69].

\section{F.2. Venöz tromboemboli profilaksisinin kullanımı ve türü:}

COVID-19 ile tromboembolik riske ilişkin doğrudan veriler sınırlı olmakla birlikte, artmış bir risk söz konusudur. Amerikan Hematoloji Derneği, Kritik Bakım Tıbbı Derneği ve Uluslararası Tromboz ve Hemostaz Derneği; COVID-19 ile hastaneye yatırılan hastalarda, bir kontrendikasyon (örn., kanama, şiddetli trombositopeni) yoksa COVID-19'lu tüm gebe/ doğum sonrası kadınlarda profilaksi önermektedir. Ciddi veya kritik hastalığı olmayan ve birkaç gün içinde doğum beklenen gebelerde antepartum profilaksi için 12 saatte bir deri altından 5000 ünite fraksiyone olmayan heparin önerilen bir dozdur [72-74]. Fraksiyone olmayan heparin, düşük moleküler ağırlıklı heparine göre daha kolay tersine çevrildiği için genellikle doğuma yakın gebelerde tercih edilir. Düşük moleküler ağırıklı heparin (örn. Günlük enoksaparin $40 \mathrm{mg}$ ), birkaç gün içinde doğum beklenmeyen ve postpartum olanlarda mantıklıdır [72-74].

\section{F.3. Deksametazon:}

COVID 19 enfeksiyonunda oksijen takviyesi veya ventilatör desteği alan, kritik hastalarda $6 \mathrm{mg} / g u ̈ n ~ d e k s a m e t a z o n u n$ 10 gün boyunca veya taburculuğa kadar kullanımı, refrakter şokun yönetiminde kullanılmaktadır. 
Akciğer maturasyonu için glukokortikoid tedavisinin zararı gösterilmemiştir ancak uygulama öncesi multidisipliner bir şeklide karar verilmelidir. COVID-19'un maternal tedavisi için glukokortikoid kullanımı kriterlerini karşılayan ve erken doğum için yüksek risk altında olan gebe kadınlarda, fetal pulmoner olgunlaşmayı indüklemek için normal dozlarda deksametazon (12 saat arayla 6 mg'lık dört doz) veya betametazon (12 mg'lık iki doz) ile fetal pulmoner olgunlaşmayı indüklemek ve ardından prednizolon (günde $40 \mathrm{mg}$ oral yoldan) veya hidrokortizon (günde iki kez intravenöz 80 mg) ile devam edilir. $\mathrm{Bu}$, fetüsün plasentayı metabolik olarak aktif bir formda geçen ve yan etkilere sahip olabilen uzun süreli bir deksametazon veya betametazona maruziyetini önler.

\section{F.4. Antiviral ilaç tedavisi:}

COVID-19 için kesin bir seçenek olmamakla beraber başka endikasyonlarda kullanılan birtakım ilaçların çalışmaları devam etmektedir. Bu çalışmalardan SOLIDARITY ve RECOVERY'i gebeleri de içeren çalışmalardır [75, 76]. Bazı merkezlerde remdesivir şiddetli formda COVID-19'u olan gebelerde kullanılmaktadır. Remdesivir, hem in vitro hem de in vivo olarak SARS-CoV-2'ye [77] ve benzer koronavirüslere (şiddetli akut solunum sendromu [SARS] ve Orta Doğu solunum sendromu ile ilişkili koronavirüs [MERS-CoV] dahil) karşı aktiviteye sahip yeni bir nükleotid analoğudur $[77,78]$. Ebola ve Marburg virüsü hastalığı olan gebelerde fetal toksisite olmadan kullanıldığı bildirilmiştir [79]. Ancak remdesivir ile yapılan tüm randomize çalışmalarda gebeler ve emzirenler çalışma dışı tutulmuştur.

Randomize çalışmalardan elde edilen veriler, genellikle hidroksiklorokin veya klorokin preparatlarının hiçbir yararı olmadığını göstermektedir. Ayrıca, advers maternal etkiler, özellikle QTc uzamasına neden olan diğer ilaçları alan hastalarda anormal kalp ritimlerine (QT aralığı uzaması ve ventriküler taşikardi) neden olabilir. Hidroksiklorokin, plasentayı geçer. Hayvan çalışmalarında fetal oküler dokudaki birikim gözlemlenmiştir, ancak insanlarda fetal oküler anormallik riskinde artış gözlenmemiştir; bu, ilacın hamile kadınlar tarafından sistemik lupus eritematozus tedavisi veya sıtma hastalığın önlenmesi için kullanıldığı göz önüne alındığında güvenlidir. Bununla birlikte, mevcut veriler sınırlıdır ve COVID-19 enfeksiyonunda farklı dozlarda kullanıldığından fetüs için risk göz önünde bulundurulmalıdır [80].

COVID-19'u olan gebelerde kullanılan bir diğer ilaç; HIV enfeksiyonunun tedavisi için de kullanılan lopinavirritonavirdir. Plasentayı geçer ve erken doğum riskini artırabilir, ancak insanlarda teratojenik etkisi yoktur. COVID-19 için denen diğer ilaçlar arasında ribavirin ve baricitinibin ise teratojeniktir.

\section{F.5. Konvelesan Plazma:}

Konvelesan plazma tedavisi COVID-19 tedavisinde destek tedavi olarak kullanılan bir yöntemdir. Konvelesan plazmanın birkaç gebe olguda, bazen ilaç tedavisi ile (örn. steroidler, remdesivir, lopinavir / ritonavir ve azitromisin) başarıla kullanıldığı bildirilmiştir [81-83]

\section{F.6. Düşük doz aspirin ve nonsteroid antiinflamatuvar ilaçlar (NSAID'ler):}

COVID-19'u olmayan hamile kadınlar için ACOG, tıbbi olarak endike olduğu şekilde düşük doz aspirinin önerilmeye devam etmesi gerektiğini belirtti (örn. preeklampsinin önlenmesi) [66].

NSAID'lerin olası olumsuz etkileri hakkındaki endişeler, pandeminin erken dönemlerinde NSAID (ibuprofen) alan ve ciddi hastalık gelişen bir olgu nedeniyle gelişmiştir [84]. Güney Kore'de COVID-19 nedeniyle hastaneye yatırılan hastalarda, hastaneye kaldırılmadan önceki yedi gün içinde NSAID kullananlar ve kullanmayanlar karşılaştırıldığında kullananlarda daha kötü klinik durum ile ilişki saptanmıştır. Ancak bu çalışmada klinik durumu kötü olanların daha yaşlı ve altta yatan komorbiditeye sahip olma oranının daha yüksek olduğu görülmüştür [85]. İsrail'den yapılan bir retrospektif çalışmada ise; NSAID kullanımı ile asetaminofen kullanımı veya antipiretik kullanımı karşılaştırıldığında, kötü klinik sonuçlar açısından fark saptanmamıştır [86. NSAID kullanımı ve kötü prognoz arasındaki ilişkide belirsizlik göz önüne alındığında, mümkünse analjezik olarak asetaminofen kullanılması önerilebilir ancak Amerikan Kadın Hastalıkları ve Doğum Uzmanları Koleji, WHO ve Avrupa İlaç Ajansı, klinik olarak endike olduğunda COVID-19 hastalarında NSAID'lerden kaçınmamayı önermektedir [66,67,87].

\section{F.7.Tokoliz:}

COVID-19 olduğu bilinen veya şüphelenilen kadınlarda, tercih edilen tokolitik nifedipindir. İndometasin; maternal kalp atış hızını daha da artırabilen beta sempatomimetikler içinde uygun bir alternatiftir. Magnezyum sülfat solunum depresyonu açısından dikkatle kullanılmalıdır.

\section{G. Fetal İzlem:}

Genellikle 25 hafta civarında fetusun viabilitesi mevcuttur. Fetal kalp atımı, kontraksiyon takibi, amniyon sıvısının miktarı, doppler USG ile fetal izlem yapılmalıdır. Hastanede yatan hastalar için, Bluetooth özellikli harici bir fetal monitör ile fetal kalp atış hızı izlemini sağlanabilir. Fetal kalp hızı izleminin yapıldığı acil sezaryen doğumun yapılacağı, hastanede yatan stabil olmayan hastalarda sürekli monitörizasyon yapılabilir. 
Stabil oksijen satürasyonu (SaO2) olan hastalarda fetal stres testi günde bir veya iki kez yapılabilir.

COVID-19 ile enfekte gebelerde fetal büyüme hakkında sınırlı veri mevcuttur. COVID 19'a bağlı akut ve kronik intervillöz inflamasyon, fokal avasküler villus ve koryonik plak ve gövde villusundaki fetal vasküler yapılarda trombüs ve uteroplasental vasküler malperfüzyona bağlı plasental yetmezlik ve buna bağlı suboptimal fetal büyüme olabilir. Bu lezyonlara COVID-19 ile ilişkili koagülopati, akut maternal hastalık sırasında plasental hipoksi, plasental viral enfeksiyon veya bu faktörlerin bir kombinasyonu da neden olabilir [15,52,88-90].

H. COVID-19'dan iyileşen kadınların takibi

Diğer SARS enfeksiyonları ile tanımlanmış olan fetal büyüme geriliği teorik bir sorundur [91, 92]. Kesin tanı almış gebelerin semptomlar düzeldikten 14 gün sonra başlayarak fetal büyüme ve amniyotik sıvı hacmi yönünden ultrasonografi ile kontrolleri önerilmektedir [15, 52, 88,90]. Illk veya ikinci trimesterde enfekte olanlar için, 18-23. gebelik haftalarında ayrıntılı bir fetal tarama önerilmektedir.

COVID-19 şüphesi olan veya doğrulanan anneler için aşağıdaki izolasyon kaldırma kriterleri belirlenmiştir [93].

- Semptomlarının ilk ortaya çıkışından sonra en az 10 gün geçmesi (kritik ve şiddetli klinik durum söz konusuysa bu süre 20 güne kadar uzatılabilir).

- En son ateş yüksekliğinin üzerinden 24 saat geçmiş olması.

- Diğer semptomları iyileşmiş olması.

Bulaşmanın önlenmesi için belirlenen bu kriterlere uyulmalıdır. Ancak SARS-CoV-2 RT-PCR sonucunun haftalarca devam etmesi viral RNA'nın varlığını göstermesine rağmen her zaman bulaştırıcılığın devam ettiği anlamına gelmemektedir [22].

\section{H. COVID 19 gebelerde doğumun planlanması}

- Hafif hastalık - Hafif semptomları olan COVID-19 tanılı gebeler için acil doğum için tıbbi / obstetrik endikasyon yoksa acil doğum endikasyonu yoktur. Pozitif annenin negatif bir test sonucu elde edildikten veya izolasyon durumu kaldırıldıktan sonra doğumun gerçekleşmesi yenidoğana doğum sonrası bulaş riskini en aza indirecektir [66]. Vital bulgular doğum sonrası takip edilmelidir. Vajinal doğumdan sonra 24 saat ve sezaryen doğumdan sonra 48 saat süreyle 4 saatte bir takip yapılmalıdır. Preterm COVID-19 tanısı olan ve tıbbi / obstetrik komplikasyonları (örn., erken membran rüptürü, preeklampsi) olan gebeler için, doğumun zamanlaması tıbbi / obstetrik bozukluk için olan protokollerle belirlenir.
- Orta derecede hastalığı olan hastalar için, ilk 24 saat boyunca semptomlar düzelene kadar kadar sürekli nabız oksimetresi ile izlem önerilir. Laboratuvar tetkikleri ve görüntülemeler hastalığın seyrine göre belirlenir.

- Şiddetli / kritik hastalık: Ciddi veya kritik hastalığı olan hastalar için, doğum ve doğum ünitesinde veya yoğun bakım ünitesinde çokyakın anne izleme ve bakımı endikedir. Ağır hastalığı olan kadınlar için doğum zamanlamasının karar verilmesinde hasta bazında birçok faktör göz önünde bulundurularak karar vermek gerekir $[25,94]$.

Annenin solunum semptomlarının doğumla düzelip düzelmeyeceği ve akut hastalığı olan annenin doğumu sırasında bulaş riski göz önünde bulundurulmalıdır. Ayrıca maternal antikor üretiminin ve dolayısıyla yenidoğanın pasif bağışıklığının gelişmesi için zamanının olmayabileceği de unutulmamalıdır. Öte yandan gebelikte oksijen tüketiminin artması ve fonksiyonel rezidüel kapasitenin azalması, pnömonili gebelerde klinik kötüleşmeye neden olabilir [95].

Çoğul gebeliklerde ise aşırı uterin distansiyon veya üçüncü trimesterde şiddetli polihidramniyos, akciğer fonksiyonunu daha da tehlikeye atabilir.

Bazı yazarlar tarafından pnömonili, ancak entübe edilmemiş COVID-19 enfekte gebeler için akciğer tutulumu arttığında gelişebilecek maternal hipoksi, fetüsü riske atabileceğinden 32-34 hafta arasında doğum önermektedir. Bazı yazarlar da, 32 haftadan önce gerçekleşecek doğumun bebeklerde bilinen morbidite ve mortalitesi göz önüne alındığında, annenin durumu ikinci haftada kötüleşebilmesine rağmen, doğumu savunmamaktadır.

COVID-19 nedeni ile entübe edilen ve kritik derecede hasta olan hastanede yatan gebenin doğum zamanlamasını planlamak zordur. Bir grup 32 ila 34 haftadan sonra hasta stabil ise doğumu savunurken, bazıları da yalnızca refrakter hipoksemik solunum yetmezliği olan veya kritik hastalığı kötüleşen hastalar için doğum yaptırmayı savunmaktadır [69]. <32 gebelik haftasında mümkün olduğu kadar fetal izleme ile devam eden maternal destek devam etmelidir. Bazı durumlarda maternal ECMO gerekli olabilir [71].

Enfekte hastadan özellikle aktif doğum sırasında olan güçlü nefes alma ile solunum damlacıklarının ve virüsün yayılması kolaylaşır ve maskenin etkinliği azalabilir [96,97]. Doğum sırasında itme esnasında dışkılama ile virüs içeren dışkı ile de bulaş riski göz önünde bulundurulmalıdır $[53,98]$.

COVID-19 şüphesi olan veya doğrulanan gebelere, travay ve doğum sırasında cerrahi maske takmaları talimatı verilir $[97,99]$. 
Birçok görüşe göre COVID-19 enfeksiyonu tek başına sezeryan endikasyonu değildir. 37 sezeryan ve 41 normal vajinal doğumun değerlendirildiği çalışmada sezeryan sonrası maternal klinik kötüleşme oranı \%22 iken normal vajinal doğumda bu oran \%5 olarak bildirilmiştir [100]. Ancak, bu çalışmada az sayıda hasta olması ve doğum yolu seçiminde yanlılık olması bulguları etkileyebilir. Asemptomatik kadınlarda, uygun tıbbi endikasyonlarla doğum eylemi ve sezaryen doğumları ertelenmemeli veya yeniden planlanmamalıdır [10].

\section{H.2. Analjezi ve Anestezi}

COVID-19 olduğu bilinen veya şüphelenilen hastalarda, nöroaksiyal anestezik kontrendike değildir ve doğum yapan hastalarda çeşitli avantajları vardır: iyi analjezi sağlar ve böylece ağrı ve anksiyeteden kaynaklanan kardiyopulmoner stresi ve dolayısıyla virus saçıımını azaltır. Acil sezaryen gerekmesi durumunda da genel anestezi ihtiyacını ortadan kaldırır. Obstetrik Anestezi ve Perinatoloji Derneği, nitröz oksit sistemlerinin temizlenmesi, filtrelenmesi ve potansiyel aerosolizasyonu ile ilgili yetersiz veri nedeniyle bu hastalarda doğum analjezisi için nitröz oksit kullanımının askıya alınmasını önermektedir.

Genel anestezi (entübasyon ve ekstübasyon) aerosol saçılmasına neden olur, bu nedenle sezaryenle doğum sırasında tüm sağlık çalışanları kişisel koruyucu ekipmanlarını tam (N-95 maskeleri, vb.) giymelidir.

Solunum yetersizliği olan kadınlarda, magnezyum sülfat kullanımına, ilaç solunumu daha da baskılayabileceğinden, duruma göre karar verilmelidir.

Doğum sonrası kanama olan COVID-19 hastalarının çoğu standart protokollere göre yönetilir. Bununla birlikte, bazı yazarlar, COVID-19 hastalarında traneksamik asitten kaçınmayı önermektedir çünkü antifibrinolitik özellikleri, şiddetli veya kritik hastalığı olanlar olanlarda tromboz riskini artırabilir [102].

Ayrıca, ağır hastalarda nadir solunum yetmezliği vakaları ve şiddetli vazokonstriksiyon ile ilişkili olduğu için metilergometrinden kaçınılmasını önermektedir.[25]

\section{H.3. Psikolojik Destek}

Tüm doğum sonrası hastalar, doğumdan dört ila sekiz hafta sonra doğum sonrası depresyon açısından taranmalıdır. En yaygın olarak kullanılan ölçek 10 maddelik Edinburgh Doğum Sonrası Depresyon Ölçeği'dir, ancak alternatifler de mevcuttur. COVID-19'un psikolojik etkisi de kabul edilmeli ve orta ila şiddetli anksiyeteyi için destek sunulmalıdır [103]

\section{Korunma önlemleri:}

Gebe kadınlar, virüse maruz kalmamak için hamile olmayan kişilerle aynı tavsiyelere uymalıdır (örn. Sosyal mesafe, el hijyeni, maske takma). COVID-19 tanısı doğrulanmış, muhtemel veya şüphelenilen bir kişiyle maskesiz yakın temas öyküsü olan gebeler 14 güne kadar izole edilmeli ve semptomlar açısından izlenmelidir [10]. Gebeler için gebelik takiplerini aksatmamaları önerilmektedir. Ancak her muayenede hijyen ve sosyal izolasyon önlemlerine uyulmalı gereksiz ziyaretler yapılmamalıdır. Ancak bu tür önlemlerin alınması evsizler, barınakta kalanlar, göçmene kampında yaşayanlar ve mülteci gebeler için güç olabilir.

Yüksek riskli gebelikleri olan gebeler de dahil olmak üzere hastaların sağlık hizmeti veren yerlerde geçirdikleri süreyi azaltmanın birçok yolu vardır. Gebelere bulaşın önlenmesi için tele tıp gibi internet aracılığıyla muayene, telefon ile danışmanlık, yüz yüze yapılan muayene sayılarının azaltılması, muayene günlerinde izlemde yapılacak testlerin toplu halde istenmesi (ör. anöploidi, diyabet, enfeksiyon taraması), muayene ve testler sırasında refakatçıların kısıtlanması, obstetrik ultrason muayenelerinin (örneğin, gebelik yaşı, fetal anomali, fetal büyüme, plasental bağlanma) sıklığının azaltılması ve sosyal mesafeye uyulması önerilir [104].

Örneğin, glikoz yükleme testinde 75 gram iki saatlik oral glikoz tolerans testi (OGTT) yerine 100 gram üç saatlik OGTT istenebilir; Down sendromu taraması için birleşik test (yani ultrason ile ense kalınlığı ve serum analizleri) yerine DNA taraması kullanılabilir (> 10 haftada). İdeal olarak, her kadının tele tıp kullanma yeteneklerine ve evde kan basıncını ölçmek için tansiyon ölçüm aletine sahip olması gerekir [10].

Genellikle gebelerin yalnızca yaklaşık 12, 20, 28 ve 36. gebelik haftalarında kontrole gelmeleri (ultrason ve / veya laboratuvar testleri) hatta bazı uygulamaların tele tıp ile yapılması, 32. haftada tek bir ziyaret yapılması önerilmektedir. Her muayenede bazal değerlendirme yapılmalıdır. Tam idrar tetkiki ve tansiyon ölçümü yapılmalıdır. İlk 3 ay ultrasonografi ile kontrol, 18-22 haftalar arasında ayrıntılı USG ile değerlendirme önerilir. Gebelikte önerilen folik asit, D vitamini gibi destek tedavilere devam edilmelidir [25].

Bu muayenelerin hastaların ve sağlık çalışanlarının maskeleri takılı bir şekilde gerçekleştirimesi ve görüntülü iletişimin teşvik edilmesi önerilmektedir. Ayrıca COVID-19'un psikolojik etkisi de göz önünde bulundurulmalı ve gebelerde şiddetli olabilen depresyon ve anksiyete de yaygın olduğu için psikolojik destek de sunulmalıdır [105-107].

SARS-CoV-2'nin asemptomatik bireylerden (veya kuluçka dönemi içindeki semptom göstermeyen bireylerden) bulaşma olasılığı göz önüne alındığında; çocuklarda COVID-19 genellikle hafif ve asemptomatik olabileceğinden, çocuklu hamile kadınlar 
daha dikkatli olmalıdır [67,108-113]. CDC çocukların diğer çocuklarla oynarken sürenin sınırlandırılmasını ve açık havada oynamalarını ve maske takmalarını önermektedir [114].

Hamile sağlık çalışanları için hangi işlerin kısıtlanması gerektiğini bildiren standart bir mesleki rehber yoktur. Sağlık hizmetleri dışındaki mesleklerde çalışan gebe çalışanlar doğum yapana kadar çalışmaya devam edebilirler, ancak risk azaltıcı önlemler (daha az riskli pozisyonlar veya kendi kendine izolasyon) bireyin peripartum enfekte olma riskini azaltmak için düşünülebilir [66]. COVID-19'u önlemede kullanılan mRNA, viral vektör ve protein/alt birim aşılarının nasıl çalıştığına ve ön klinik verilere dayanarak, gebelik planlayan kişiler, gebeler, emzirenler, fetüs veya yenidoğanlar için risk oluşturma olasılığının düşük olduğu gösterilmiştir. Aşılanmış gebelerden ve küçük prospektif kohort çalışmalarından elde edilen verilerde, zararlı etkiler görülmemiştir ve maternal aşılamadan sonra yenidoğanlarda SARS-CoV-2'ye karşı antikorlar tespit edilmiş ve anne antikorlarının plasentadan ve anne sütüne transfer edildiği gösterilmiştir [115].

\section{J. COVID 19 tanılı anneden doğan yenidoğanın izlemi}

Yenidoğanın SARS-CoV-2'yi annesinden alma riski düşüktür ve veriler, ister yeni doğan bebeğe ayrı bir odada bakılsın, ister annenin odasında kalsın, neonatal SARS-CoV-2 enfeksiyonu riskinde hiçbir fark olmadığını göstermektedir. Anneler, bebekleriyle temas sırasında bir maske takmalı ve el hijyeni uygulamalı ve diğer zamanlarda anne ile yenidoğan arasında fiziksel mesafenin korunmalıdır.

Birkaç vaka serisinde COVID-19'lu annelerden alınan tüm anne sütü örneklerinin negatif olduğunu bildirmesine rağmen, anne sütü ile SARS-CoV-2 bulaşma riski henüz net olarak bilinmemektedir [46, 116]. Daha sonra yapılan çalışmalarda bazı araştırmacılar tarafından anne sütü örneklerinde virüs saptandığı bildirilmiştir [15, 20, 21].

BirWHO çalışmasında, 43 anneden alınan anne sütüörneklerinde RT-PCR ile SARS-CoV-2 negatif bulurken ve üç anneden alınan numuneler pozitif olarak tespit edilmiş, ancak virüsün canlılığı ve enfektivitesi açısından ek testler yapılmamıştır [117]. SARSCoV-2 testi pozitif çıkan ve emzirmeye devam eden annelerin 82 bebeği test edilmiş ve doğumdan sonra hiçbir bebek SARSCoV-2 pozitif bulunmamıştır [50].

Sonuç olarak anne sütünün faydaları, anne sütünün içeridiği antikorların bebek için pasif antikor koruması sağlayabileceği göz ününe alındığında emzirmenin devam ettirilmesi önerilir. Ancak emzirme öncesi ve sonrası el hijyenine dikkat etmeli ve emzirme sırasında maske takmalıdır.
COVID-19'u doğrulanmış annelerde veya COVID-19 şüphesi olan semptomatik annelerde, ideal olarak doğrudan teması en aza indirmek için, anne iyileşene veya diğer bakıcının sağlıklı olması koşuluyla, bebeğe başka bir bakıcı tarafından sağılmış anne sütü verilmesi tercih ediliyorsa pompa ile süt sağılabilir. Böyle durumlarda anne pompalamadan önce maske takmalı ve ellerini ve göğüslerini iyice temizlemelidir; pompa parçaları ve şişeler temizlenmelidir. Bakıcı tarafından sağlanan işlemler (örneğin, çocuk bezi değiş̧tirmek, banyo yaptırmak, beslemek) sırasında, uygun kişisel koruyucu ekipman kullanmalıdır (önlük, eldiven, yüz maskesi ve göz koruması) [10].

\section{Kaynaklar}

1. Breslin N, Baptiste C, Gyamfi-Bannerman C, et al. COVID-19 infection among asymptomatic and symptomatic pregnant women: Two weeks of confirmed presentations to an affiliated pair of New York City hospitals. Am J Obstet Gynecol MFM 100118 . 2020; https://doi.org/10.1016/j.ajogmf.2020.100118,

2. Sutton $D$, Fuchs $K, D^{\prime}$ Alton $M$, et al. Universal Screening for SARSCoV-2 in Women Admitted for Delivery. N Engl J Med 382:21634. 2020; . https://doi.org/10.1056/NEJMc2009316

3. Di Mascio D, Khalil A, Saccone G, et al. Outcome of Coronavirus spectrum infections (SARS, MERS, COVID 1 -19) during pregnancy: a systematic review and meta-analysis. Am J Obstet Gynecol MFM 100107. 2020; . https://doi.org/10.1016/j. ajogmf.2020.100107

4. Schwartz DA An Analysis of 38 Pregnant Women with COVID-19, Their Newborn Infants, and Maternal-Fetal Transmission of SARS-CoV-2: Maternal Coronavirus Infections and Pregnancy Outcomes. Arch Pathol Lab Med. 2020; https://doi.org/10.5858/ arpa.2020-0901-SA

5. Khan S, Jun L, Nawsherwan null, et al. Association of COVID-19 with pregnancy outcomes in health-care workers and general women. Clin Microbiol Infect Off Publ Eur Soc Clin Microbiol Infect Dis 26:788-90 . 2020; https://doi.org/10.1016/j.cmi.2020.03.034

6. Yang H, Sun G, Tang F, et al. Clinical features and outcomes of pregnant women suspected of coronavirus disease 2019. J Infect 81:e40-e44 . 2020; https://doi.org/10.1016/j.jinf.2020.04.003

7. Della Gatta AN, Rizzo R, Pilu G, et al. Coronavirus disease 2019 during pregnancy: a systematic review of reported cases. Am J Obstet Gynecol 223:36-41 . 2020; https://doi.org/10.1016/j. ajog.2020.04.013

8. Li N, Han L, Peng M, et al. Maternal and neonatal outcomes of pregnant women with COVID-19 pneumonia: a case-control study. Clin Infect Dis Off Publ Infect Dis Soc Am. 2020; https:// doi.org/10.1093/cid/ciaa352 
9. Badr DA, Mattern J, Carlin A, et al. Are clinical outcomes worse for pregnant women at $\geq 20$ weeks' gestation infected with coronavirus disease 2019? A multicenter case-control study with propensity score matching. Am J Obstet Gynecol 2020; 223:764.

10. Coronavirus disease 2019 (COVID-19): Pregnancy issues UpToDate. https://www.uptodate.com/contents/coronavirusdisease-2019-covid-19-pregnancy issues?search=covid\%20 pregnancy\&source=search_result\&selectedTitle=1 150\&usag e_type $=$ default\&display_rank=1. Accessed 6 Aug 2020

11. Sutton D, Fuchs $K, D^{\prime} A$ lton $M$, et al. Universal Screening for SARSCoV-2 in Women Admitted for Delivery. N Engl J Med. 2020; https://doi.org/10.1056/NEJMc2009316

12. Campbell KH, Tornatore JM, Lawrence KE, et al. Prevalence of SARS-CoV-2 Among Patients Admitted for Childbirth in Southern Connecticut. JAMA. 2020; https://doi.org/10.1001/ jama.2020.8904

13. LaCourse SM, Kachikis A, Blain M, et al. Low prevalence of SARSCoV-2 among pregnant and postpartum patients with universal screening in Seattle, Washington. Clin Infect Dis Off Publ Infect Dis Soc Am. 2020; https://doi.org/10.1093/cid/ciaa675

14. Goldfarb IT, Diouf K, Barth WH, et al.Universal SARS-CoV-2 testing on admission to the labor and delivery unit: Low prevalence among asymptomatic obstetric patients. Infect Control Hosp Epidemiol 1-2 . 2020;https://doi.org/10.1017/ice.2020.255

15. Kirtsman M, Diambomba $Y$, Poutanen SM, et al. () Probable congenital SARS-CoV-2 infection in a neonate born to a woman with active SARS-CoV-2 infection. CMAJ Can Med Assoc J J Assoc Medicale Can 192:647-50. 2020; . https://doi.org/10.1503/ cmaj.200821

16. Dong L, Tian J, He S, et al. Possible Vertical Transmission of SARSCoV-2 From an Infected Mother to Her Newborn. JAMA. 2020 https://doi.org/10.1001/jama.2020.4621

17. Zeng L, Xia S, Yuan W, et al. Neonatal Early-Onset Infection With SARS-CoV-2 in 33 Neonates Born to Mothers With COVID-19 in Wuhan, China. JAMA Pediatr. 2020; https://doi.org/10.1001/ jamapediatrics.2020.0878

18. Baud D, Greub G, Favre G, et al. Second-Trimester Miscarriage in a Pregnant Woman With SARS-CoV-2 Infection. JAMA. 2020; https://doi.org/10.1001/jama.2020.7233

19. Zeng $\mathrm{H}, \mathrm{Xu} \mathrm{C}$, Fan J, et al. (Antibodies in Infants Born to Mothers With COVID-19 Pneumonia. JAMA 323:1848-9 . 2020; https:// doi.org/10.1001/jama.2020.4861

20. Wu Y, Liu C, Dong L, et al.Coronavirus disease 2019 among pregnant Chinese women: case series data on the safety of vaginal birth and breastfeeding. BJOG Int J Obstet Gynaecol. 2020; https://doi.org/10.1111/1471-0528.16276
21. Groß R, Conzelmann C, Müller JA, et al. Detection of SARS-CoV-2 in human breastmilk. Lancet Lond Engl 395:1757-8 . 2020; https://doi.org/10.1016/S0140-6736(20)31181-8

22. Interpreting Diagnostic Tests for SARS-CoV-2 - PubMed. https:// pubmed.ncbi.nlm.nih.gov/32374370/. Accessed 17 Aug 2020

23. Kucirka LM, Lauer SA, Laeyendecker O, et al.Variation in FalseNegative Rate of Reverse Transcriptase Polymerase Chain Reaction-Based SARS-CoV-2 Tests by Time Since Exposure. Ann Intern Med. 2020; https://doi.org/10.7326/M20-1495

24. Kelly JC, Dombrowksi M, O'neil-Callahan M, et al. () False-Negative COVID-19 Testing: Considerations in Obstetrical Care. Am J Obstet Gynecol MFM 100130 , 2020; https://doi.org/10.1016/j. ajogmf.2020.100130

25. Donders F, Lonnée-Hoffmann R, Tsiakalos A, et al. Isidog Covid-Guideline Workgroup null ISIDOG Recommendations Concerning COVID-19 and Pregnancy. Diagn Basel Switz 10: 2020; https://doi.org/10.3390/diagnostics10040243

26. World Health Organization. Coronavirus disease (COVID-19) technical guidance: Surveillance and case definitions. https:// www.who.int/emergencies/diseases/novel-coronavirus-2019/ technical-guidance/surveillance-and-case-definitions (Accessed on February 28, 2020).

27. How to perform lung ultrasound in pregnant women with suspected COVID-19 - PubMed. https://pubmed.ncbi.nlm.nih. gov/32207208/. Accessed 17 Aug 2020

28. Buonsenso D, Raffaelli F, Tamburrini E, et al. Clinical role of lung ultrasound for diagnosis and monitoring of COVID-19 pneumonia in pregnant women. Ultrasound Obstet Gynecol Off J Int Soc Ultrasound Obstet Gynecol 56:106-9 . 2020; https://doi. org/10.1002/uog.22055

29. Badr DA, Mattern J, Carlin A, et al. Are clinical outcomes worse for pregnant women at $\geq 20$ weeks' gestation infected with coronavirus disease 2019? A multicenter case-control study with propensity score matching. Am J Obstet Gynecol 2020; 223:764.

30. Huntley BJF, Huntley ES, Di Mascio D, et al .Rates of Maternal and Perinatal Mortality and Vertical Transmission in Pregnancies Complicated by Severe Acute Respiratory Syndrome Coronavirus 2 (SARS-Co-V-2) Infection: A Systematic Review. Obstet Gynecol 136:303-12 . 2020; https://doi.org/10.1097/ AOG.0000000000004010

31. NIH COVID-19 Treatment Guidelines https:// covid19treatmentguidelines.nih.gov/overview/managementof-covid-19/ (Accessed on April 22, 2020). 
32. Karimi L, Makvandi S, Vahedian-Azimi A, et al. Effect of COVID-19 on Mortality of Pregnant and Postpartum Women: A Systematic Review and Meta-Analysis. J Pregnancy 2021; 2021:8870129.

33. Characteristics and Outcomes of 241 Births to Women With Severe Acute Respiratory Syndrome Coronavirus 2 (SARS-CoV-2) Infection at Five New York City Medical Centers - PubMed. https:// pubmed.ncbi.nlm.nih.gov/32555034/. Accessed 15 Aug 2020

34. Crovetto F, Crispi F, Llurba E, et al. Seroprevalence and presentation of SARS-CoV-2 in pregnancy. Lancet Lond Engl. 2020; https://doi.org/10.1016/S0140-6736(20)31714-1

35. COVID-19 and HELLP: Overlapping Clinical Pictures in Two Gravid Patients - PubMed. https://pubmed.ncbi.nlm.nih. gov/32566368/. Accessed 18 Aug 2020

36. Mendoza M, Garcia-Ruiz I, Maiz N, et al.Pre-eclampsialike syndrome induced by severe COVID-19: a prospective observational study. BJOG Int J Obstet Gynaecol. 2020; https:// doi.org/10.1111/1471-0528.16339

37. Zitiello A, Grant GE, Ben Ali N, et al. Thrombocytopaenia in pregnancy: the importance of differential diagnosis during the COVID-19 pandemic. J Matern-Fetal Neonatal Med Off J Eur Assoc Perinat Med Fed Asia Ocean Perinat Soc Int Soc Perinat Obstet 1-3 .2020: https://doi.org/10.1080/14767058.2020.1786527

38. Mullins E, Evans D, Viner RM, et al.Coronavirus in pregnancy and delivery: rapid review. Ultrasound Obstet Gynecol Off J Int Soc Ultrasound Obstet Gynecol 55:586-92 . 2020; https://doi. org/10.1002/uog.22014

39. Clinical Findings and Disease Severity in Hospitalized Pregnant Women With Coronavirus Disease 2019 (COVID-19) - PubMed. https://pubmed.ncbi.nlm.nih.gov/32433453/. Accessed 15 Aug 2020

40. Knight M, Bunch K, Vousden N, et al. UK Obstetric Surveillance System SARS-CoV-2 Infection in Pregnancy Collaborative Group .Characteristics and outcomes of pregnant women admitted to hospital with confirmed SARS-CoV-2 infection in UK: national population based cohort study. BMJ 369:m2107 . 2020; https:// doi.org/10.1136/bmj.m2107

41. Hantoushzadeh S, Shamshirsaz AA, Aleyasin A, et al. Maternal death due to COVID-19. Am J Obstet Gynecol 223:109.e1-109. e16. 2020; . https://doi.org/10.1016/j.ajog.2020.04.030

42. Ahmed I, Azhar A, Eltaweel N, et al. First COVID-19 maternal mortality in the UK associated with thrombotic complications. Br J Haematol 190:e37-e38 2020; https://doi.org/10.1111/ bjh.16849

43. Blitz MJ, Rochelson B, Minkoff $\mathrm{H}$, et al. Maternal mortality among women with coronavirus disease 2019 admitted to the intensive care unit. Am J Obstet Gynecol. 2020; https://doi.org/10.1016/j. ajog.2020.06.020
44. Takemoto MLS, Menezes M de O, Andreucci CB, et al.The tragedy of COVID-19 in Brazil: 124 maternal deaths and counting. Int J Gynaecol Obstet Off Organ Int Fed Gynaecol Obstet. 2020; https://doi.org/10.1002/ijgo.13300

45. Weekly COVID-19 Pregnancy Data www.cdc.gov (Accessed on August 11, 2020).

46. Elshafeey F, Magdi R, Hindi N, et al. A systematic scoping review of COVID-19 during pregnancy and childbirth. Int J Gynaecol Obstet Off Organ Int Fed Gynaecol Obstet 150:47-52 . 2020; https://doi.org/10.1002/ijgo.13182

47. Coronavirus disease 2019 in pregnant women: a report based on 116 cases - PubMed. https://pubmed.ncbi.nlm.nih. gov/32335053/. Accessed 15 Aug 2020

48. Li J, Wang Y, Zeng $Y$, et al. Critically ill pregnant patient with COVID-19 and neonatal death within two hours of birth. Int J Gynaecol Obstet Off Organ Int Fed Gynaecol Obstet 150:126-8 . 2020; https://doi.org/10.1002/ijgo.13189

49. Kotlyar A, Grechukhina O, Chen A, et al. Vertical Transmission of COVID-19: A Systematic Review and Meta-analysis. Am J Obstet Gynecol. 2020; https://doi.org/10.1016/j.ajog.2020.07.049

50. Salvatore CM, Han J-Y, Acker KP, et al. Neonatal management and outcomes during the COVID-19 pandemic: an observation cohort study. Lancet Child Adolesc Health. 2020; https://doi. org/10.1016/S2352-4642(20)30235-2

51. Shah PS, Diambomba Y, Acharya G, et al. Classification system and case definition for SARS-CoV-2 infection in pregnant women, fetuses, and neonates. Acta Obstet Gynecol Scand 99:565-8 . 2020; https://doi.org/10.1111/aogs.13870

52. Vivanti AJ, Vauloup-Fellous C, Prevot $S$, et al. Transplacental transmission of SARS-CoV-2 infection. Nat Commun 11:3572 . 2020; https://doi.org/10.1038/s41467-020-17436-6

53.

54. Patanè $L$, Morotti $D$, Giunta MR, et al. Vertical transmission of COVID-19: SARS-CoV-2 RNA on the fetal side of the placenta in pregnancies with COVID-19 positive mothers and neonates at birth. Am J Obstet Gynecol MFM 100145 . 2020; https://doi. org/10.1016/j.ajogmf.2020.100145

55. Wang $W, X u Y$, Gao R, et al. Detection of SARS-CoV-2 in Different Types of Clinical Specimens. JAMA. 2020; https://doi. org/10.1001/jama.2020.3786

56. Pique-Regi R, Romero R, Tarca AL, et al.Does the human placenta express the canonical cell entry mediators for SARS-CoV-2? eLife 9: . 2020; https://doi.org/10.7554/eLife.58716 
57. Hecht JL, Quade B, Deshpande V, et al. SARS-CoV-2 can infect the placenta and is not associated with specific placental histopathology: a series of 19 placentas from COVID-19-positive mothers. Mod Pathol Off J U S Can Acad Pathol Inc. 2020; https:// doi.org/10.1038/s41379-020-0639-4

58. Walker KF, O'Donoghue K, Grace N, et al. Maternal transmission of SARS-COV-2 to the neonate, and possible routes for such transmission: a systematic review and critical analysis. BJOG Int J Obstet Gynaecol. 2020; https://doi.org/10.1111/14710528.16362

59. Qiu L, Liu X, Xiao M, et al. SARS-CoV-2 Is Not Detectable in the Vaginal Fluid of Women With Severe COVID-19 Infection. Clin Infect Dis Off Publ Infect Dis Soc Am 71:813-817 . 2020; https:// doi.org/10.1093/cid/ciaa375

60. Chen H, Guo J, Wang C, et al.() Clinical characteristics and intrauterine vertical transmission potential of COVID-19 infection in nine pregnant women: a retrospective review of medical records. Lancet Lond Engl 395:809-15 . 2020; https:// doi.org/10.1016/S0140-6736(20)30360-3

61. https://smfm.org

62. Centers for Disease Control and Prevention. Interim Infection Prevention and Control Recommendations for Healthcare Personnel During the Coronavirus Disease 2019 (COVID-19) Pandemic. https:// www.cdc.gov/coronavirus/2019-ncov/hcp/infection-controlrecommendations.html (Accessed on July 14, 2020).

63. Interim Considerations for Infection Prevention and Control of Coronavirus Disease 2019 (COVID-19) in Inpatient Obstetric Healthcare Settings https://www.cdc.gov/coronavirus/2019ncov/hcp/inpatient-obstetric-healthcare-guidance.html (Accessed on April 09, 2020).

64. Breslin N, Baptiste C, Miller R, Fuchs K, Goffman D, GyamfiBannerman C, D'Alton M (2020) Coronavirus disease 2019 in pregnancy: early lessons. Am J Obstet Gynecol MFM 2:100111 . https://doi.org/10.1016/j.ajogmf.2020.100111

65. Berghella V. Coronavırus Guıdance - From Ajog Mfm. Now!: Protection for Obstetrical providers and Patients . https:// els-jbs-prod-cdn.jbs.elsevierhealth.com/pb/assets/raw/ Health\%20Advance/journals/ymob/Proetection_Ob_Prov_Pts1584979215463.pdf (Accessed on March 31, 2020).

66. www.ACOG.org (Accessed on July 02, 2020).

67. Rothe C, Schunk M, Sothmann P, et al. Transmission of 2019nCoV Infection from an Asymptomatic Contact in Germany. N Engl J Med 382:970-971 . 2020; https://doi.org/10.1056/ NEJMc2001468
68. World Health Organization (WHO). Clinical management of severe acute respiratory infection (SARI) when COVID-19 disease is suspected" interim guidance 27 May 2020.

69. Tolcher MC, McKinney JR, Eppes CS, et al. Prone Positioning for Pregnant Women With Hypoxemia Due to Coronavirus Disease 2019 (COVID-19). Obstet Gynecol 136:259-61 . 2020; https://doi. org/10.1097/AOG.0000000000004012

70. Pacheco LD, Saad A. Ventilator management in critical illness. In: Critical Care Obstetrics, 6th ed, Phelan JP, Pacheco LD, Foley MR, et al (Eds), Wiley-Blackwell, 2018.

71. Webster CM, Smith KA, Manuck TA Extracorporeal membrane oxygenation in pregnant and postpartum women: a ten-year case series. Am J Obstet Gynecol MFM 20202100108

72. Thachil J, Tang N, Gando S, et al. ISTH interim guidance on recognition and management of coagulopathy in COVID-19. J Thromb Haemost JTH 18:1023-1026 . 2020; https://doi. org/10.1111/jth.14810

73. American Society of Hematology. COVID-19 and VTE/ Anticoagulation: Frequently Asked Questions. https://www. hematology.org/covid-19/covid-19-and-vte-anticoagulation (Accessed on April 24, 2020).

74. Society of Critical Care Medicine. COVID-19 Guidelines. https://www.sccm.org/SurvivingSepsisCampaign/Guidelines/ COVID-19 (Accessed on April 24, 2020).

75. Public health emergency SOLIDARITY trial of treatments for COVID-19 infection in hospitalized patients. http://www.isrctn. com/ISRCTN83971151 (Accessed on July 20, 2020).

76. RECOVERY. Randomised Evaluation of COVID-19 Therapy. https://www.recoverytrial.net/ (Accessed on July 20, 2020).

77. Wang $M$, Cao R, Zhang $L$, et al. Remdesivir and chloroquine effectively inhibit the recently emerged novel coronavirus (2019-nCoV) in vitro. Cell Res 30:269-271 . 2020; https://doi. org/10.1038/s41422-020-0282-0

78. Sheahan TP, Sims AC, Graham RL, et al. Broad-spectrum antiviral GS-5734 inhibits both epidemic and zoonotic coronaviruses. Sci Transl Med 9: . 2017; https://doi.org/10.1126/scitranslmed.aal3653

79. Mulangu S, Dodd LE, Davey RT, et al. PALM Consortium Study Team A Randomized, Controlled Trial of Ebola Virus Disease Therapeutics. N Engl J Med 381:2293-2303 . 2019; https://doi. org/10.1056/NEJMoa1910993

80. Lacroix I, Bénévent J, Damase-Michel C Chloroquine and hydroxychloroquine during pregnancy: What do we know? Therapie. 2020; https://doi.org/10.1016/j.therap.2020.05.004 
81. Grisolia G, Franchini M, Glingani C, et al Convalescent plasma for COVID-19 in pregnancy: a case report and review. Am J Obstet Gynecol MFM 2020

82. Zhang B, Liu S, Tan T,et al. Treatment With Convalescent Plasma for Critically III Patients With Severe Acute Respiratory Syndrome Coronavirus 2 Infection. Chest 158:e9-e13 . 2020; https://doi. org/10.1016/j.chest.2020.03.039

83. Anderson J, Schauer J, Bryant S, et al.The use of convalescent plasma therapy and remdesivir in the successful management of a critically ill obstetric patient with novel coronavirus 2019 infection: A case report. Case Rep Womens Health e00221 . 2020; https://doi.org/10.1016/j.crwh.2020.e00221

84. Day M Covid-19: ibuprofen should not be used for managing symptoms, say doctors and scientists. BMJ 368:m1086 . 2020; https://doi.org/10.1136/bmj.m1086

85. Jeong $H E$, Lee $H$, Shin $H J$, et al. Association between NSAIDs use and adverse clinical outcomes among adults hospitalized with COVID-19 in South Korea: A nationwide study. Clin Infect Dis Off Publ Infect Dis Soc Am. 2020; https://doi.org/10.1093/cid/ciaa1056

86. Rinott E, Kozer E, Shapira Y, et al. Ibuprofen use and clinical outcomes in COVID-19 patients. Clin Microbiol Infect Off Publ Eur Soc Clin Microbiol Infect Dis. 2020; https://doi.org/10.1016/j. cmi.2020.06.003

87. European Medicines Agency. EMA gives advice on the use of non-steroidal anti-inflammatories for COVID-19 https://www. ema.europa.eu/en/news/ema-gives-advice-use-non-steroidalanti-inflammatories-covid-19 (Accessed on March 19, 2020).

88. Shanes ED, Mithal LB, Otero S, et al. Placental Pathology in COVID-19. Am J Clin Pathol 154:23-32 . 2020; https://doi. org/10.1093/ajcp/aqaa089

89. Prabhu M, Cagino K, Matthews KC, et al. Pregnancy and postpartum outcomes in a universally tested population for SARS-CoV-2 in New York City: a prospective cohort study. BJOG Int J Obstet Gynaecol. 2020; https://doi.org/10.1111/14710528.16403

90. Smithgall MC, Liu-Jarin X, Hamele-Bena D, et al. Third Trimester Placentas of SARS-CoV-2-Positive Women: Histomorphology, including Viral Immunohistochemistry and in Situ Hybridization. Histopathology. 2020; https://doi.org/10.1111/his.14215

91. Wong SF, Chow KM, Leung TN, et al. Pregnancy and perinatal outcomes of women with severe acute respiratory syndrome. Am J Obstet Gynecol 191:292-297 . 2004; https://doi.org/10.1016/j. ajog.2003.11.019
92. Ng WF, Wong SF, Lam A, et al.() The placentas of patients with severe acute respiratory syndrome: a pathophysiological evaluation. Pathology (Phila) 38:210-8 . 2006; https://doi. org/10.1080/00313020600696280

93. CDC. Care for newborns. https://www.cdc.gov/coronavirus/2019ncov/hcp/caring-for-newborns.html (Accessed on August 04, 2020).

94. Chen $D$, Yang $H$, Cao $Y$, et al. Expert consensus for managing pregnant women and neonates born to mothers with suspected or confirmed novel coronavirus (COVID-19) infection. Int J Gynaecol Obstet Off Organ Int Fed Gynaecol Obstet 149:130-6 . 2020; https://doi.org/10.1002/ijgo.13146

95. Stephens AJ, Barton JR, Bentum N-AA, et al. General Guidelines in the Management of an Obstetrical Patient on the Labor and Delivery Unit during the COVID-19 Pandemic. Am J Perinatol 37:829-836. 2020; https://doi.org/10.1055/s-0040-1710308

96. Jamieson DJ, Steinberg JP, Martinello RA, et al. Obstetricians on the Coronavirus Disease 2019 (COVID-19) Front Lines and the Confusing World of Personal Protective Equipment. Obstet Gynecol 135:1257-1263 . 2020; https://doi.org/10.1097/ AOG.0000000000003919

97. Boelig RC, ManuckT, Oliver EA, et al. Labor and delivery guidance for COVID-19. Am J Obstet Gynecol MFM 2:100110 . 2020; https:// doi.org/10.1016/j.ajogmf.2020.100110

98. Zhang W, Du R-H, Li B, et al. Molecular and serological investigation of 2019-nCoV infected patients: implication of multiple shedding routes. Emerg Microbes Infect 9:386-389 . 2020; https://doi.org/10.1080/22221751.2020.1729071

99. Berghella $\mathrm{V}$ NOW!: protection for obstetrical providers and patients. Am J Obstet Gynecol MFM 100109 . 2020; https://doi. org/10.1016/j.ajogmf.2020.100109

100. Martínez-Perez O, Vouga M, Cruz Melguizo S, et al. Association Between Mode of Delivery Among Pregnant Women With COVID-19 and Maternal and Neonatal Outcomes in Spain. JAMA. 2020; https://doi.org/10.1001/jama.2020.10125

101. Consıderatıons For Obstetrıc Anesthesıa Care Related To Covid-19 https://soap.org/education/provider-education/expertsummaries/interim-considerations-for-obstetric-anesthesia-carerelated-to-covid19/ (Accessed on March 30, 2020).

102. Ogawa $H$, Asakura $H$ Consideration of Tranexamic Acid Administration to COVID-19 Patients. Physiol Rev 100:15951596 . 2020; https://doi.org/10.1152/physrev.00023.2020

103. Cox JL, Holden JM, Sagovsky R et al. Detection of postnatal depression. Development of the 10-item Edinburgh Postnatal Depression Scale. Br J Psychiatry J Ment Sci 150:782-6 . 1987; https://doi.org/10.1192/bjp.150.6.782 
104. Boelig RC, Saccone G, Bellussi F, et al.MFM guidance for COVID-19. Am J Obstet Gynecol MFM 100106 . 2020; https://doi. org/10.1016/j.ajogmf.2020.100106

105. Immediate Psychological Responses and Associated Factors during the Initial Stage of the 2019 Coronavirus Disease (COVID-19) Epidemic among the General Population in China - PubMed. https://pubmed.ncbi.nlm.nih.gov/32155789/. Accessed 18 Aug 2020

106. Berthelot N, Lemieux R, Garon-Bissonnette J, et al. Uptrend in distress and psychiatric symptomatology in pregnant women during the coronavirus disease 2019 pandemic. Acta Obstet Gynecol Scand 99:848-855 . 2020; https://doi.org/10.1111/ aogs.13925

107. Wu Y, Zhang C, Liu $H$, et al. Perinatal depressive and anxiety symptoms of pregnant women during the coronavirus disease 2019 outbreak in China. Am J Obstet Gynecol 223:240.e1-240.e9 .2020; https://doi.org/10.1016/j.ajog.2020.05.009

108. KupferschmidtFeb. 3 K, 2020, Pm 5:30 Study claiming new coronavirus can be transmitted by people without symptoms was flawed. In: Sci. AAAS. 2020; https://www.sciencemag.org/ news/2020/02/paper-non-symptomatic-patient-transmittingcoronavirus-wrong. Accessed 6 Aug 2020

109. Yu P, Zhu J, Zhang Z, Han Y A Familial Cluster of Infection Associated With the 2019 Novel Coronavirus Indicating Possible Person-to-Person Transmission During the Incubation Period. J Infect Dis 221:1757-1761 . 2020; https://doi.org/10.1093/infdis/ jiaa077

110. Bai Y, Yao L, Wei T, et al. Presumed Asymptomatic Carrier Transmission of COVID-19. JAMA. 2020; https://doi.org/10.1001/ jama.2020.2565
111. Hu Z, Song $C, X u C$, et al. Clinical characteristics of 24 asymptomatic infections with COVID-19 screened among close contacts in Nanjing, China. Sci China Life Sci 63:706-11 . 2020; https://doi.org/10.1007/s11427-020-1661-4

112. Qian G, Yang N, Ma AHY, et al. COVID-19 Transmission Within a Family Cluster by Presymptomatic Carriers in China. Clin Infect Dis Off Publ Infect Dis Soc Am 71:861-862 . 2020; https://doi. org/10.1093/cid/ciaa316

113. He X, Lau EHY, Wu P, et al. Temporal dynamics in viral shedding and transmissibility of COVID-19. Nat Med 26:672-675. 2020; https://doi.org/10.1038/s41591-020-0869-5

114. United States Centers for Disease Control and Prevention. Coronavirus disease 2019 (COVID-19). Help stop the spread of COVID-19 in children. Tips to protect children during a COVID-19 outbreak. Available at: https://www.cdc.gov/coronavirus/2019ncov/daily-life-coping/children/protect-children.html (Accessed on July 29, 2020).

115. Male V. Are COVID-19 vaccines safe in pregnancy? Nat Rev Immunol 2021;21:200.

116. Liu W, Wang J, Li W, et al.Clinical characteristics of 19 neonates born to mothers with COVID-19. Front Med 14:193-8. 2020; https://doi.org/10.1007/s11684-020-0772-y

117. WHO. Breastfeeding and COVID-19. Scientific Brief. 23 June 2020 https://www.who.int/publications/i/item/10665332639 (Accessed on June 25, 2020). 